\title{
Catching up, falling behind: the need to build upgrading coalitions for innovation and inclusive development in South Africa
}

Catching up, falling behind: a necessidade de coalizões políticas para inovação e desenvolvimento inclusivo na África do Sul

Glenda Kruss (1)

(1) Human Sciences Research Council of South Africa

\begin{abstract}
Through analysis of the South African case, a country stalled in a middle income trap, the paper aims to add to the literature on catchup. It uses Albuquerque's (2019) model of the vicious cycles arising from inequality and income concentration, together with the notion of 'upgrading coalitions' (Doner and Schneider 2016) required to challenge these vicious cycles, to analyse the persistence of lock-ins. It then analyses a global astronomy project, a 'window of opportunity' building on historically grown capabilities, promoted by 'upgrading coalitions' operating in the national interest. In contrast, it proposes a 'detour' to build domestic capabilities, driven by an upgrading coalition centred on local economic development and livelihoods in the informal economy. The paper aims to reinforce the evidence on how inequality is both a cause and consequence of a middle income trap, and open debate on how upgrading coalitions may be a critical strategy for breaking lock-ins.
\end{abstract}

\section{Keywords}

middle income trap, inequality, upgrading coalitions, lock-ins, South Africa.

JEL Codes O33, O38, O20, O11, O17, O55.

\section{Resumo}

Esse artigo contribui para a literatura sobre catch-up econômico por meio da análise do caso da África do Sul, um país preso em uma armadilha de renda média. Ele usa o modelo dos ciclos viciosos decorrentes da desigualdade e da concentração de renda de Albuquerque (2019), juntamente com a noção de "coalizões de aprimoramento" (Doner e Schneider 2016) necessária para desafiar esses ciclos viciosos, para analisar a persistência de lock-ins. Em seguida, analisa um projeto de astronomia global, uma "janela de oportunidade" baseada em capacitações historicamente cultivadas, promovida por coalizões de aprimoramento operando no interesse nacional. Em contraste, se propõe um 'desvio' para construir capacitações domésticas, impulsionado por uma coalizão de aprimoramento centrada no desenvolvimento econômico local e nos meios de vida na economia informal. $O$ artigo tem como objetivo reforçar a evidência de como a desigualdade é tanto causa quanto consequência de uma armadilha de renda média e ampliar o debate sobre como as coalizões de aprimoramento podem ser uma estratégia crítica para quebrar lock-ins.

\section{Palavras-chave}

armadilha da renda média, desigualdade, coalizões de aprimoramento, lock-ins, África do Sul.

Códigos JEL O33, O38, O20, O11, O17, 055 . 


\section{Introduction}

Since the end of the apartheid political system and the transition to a democratic dispensation in 1994, there have been great expectations and hopes for economic catch-up in South Africa, a middle income country that stagnated for decades. In a seminal work, Gill and Kharas (2007) define a 'middle income trap' as when a country experiences a sharp deceleration of growth after a period of sustained growth in per capita income. The concept stimulated research and policy debate on the appropriate growth theory and development policy to be applied in middle-income countries (Gill and Kharas 2015; Pruchnik and Zowczak 2017; Yusuf 2017). Over the past 25 years, since the democratic elections of 1994, the South African state has not been able to implement policy to drive diversification, productivity, innovation and inclusive growth, suggesting that South Africa is firmly caught in a middle income trap, struggling to emerge from a long period of decelerated growth (Bhorat et al. 2014; 2015), with the possibility of 'falling behind':

South Africa's performance on a range of social, economic and governance measures deteriorated more in the past 12 years than any other nation not at war (Sguazzin 2019).

The development challenge posed by an emerging economy like South Africa is: how do we extricate the economy and innovation system from the lock-in of the middle income trap, and onto a renewed development path? The paper aims to analyse the conditions underlying such a negative trajectory, and identify spaces and mechanisms for breaking the lock-in.

It does so by drawing on three conceptual models in the literature. First, the models linking middle income traps and catch up (Lee 2013; 2019; Gill and Kharas 2015; Pruchnik and Zowczak 2017; Fu et al. 2010; Yusuf 2017), which must be used with care in each country case, because of the very different, path dependent nature of economic development. At the centre of analysis must be the recognition that 'apartheid and the historic dependence on mineral exports left South Africa with unusually deep inequalities and joblessness' (Makgetla 2013:3), and that extreme inequality is a major constraint.

Second, therefore, are emergent conceptual models that recognise how income concentration and inequality may lie at the heart of the lock in of 
a middle income trap. Albuquerque (2019)'s framework for analysing how inequality in Brazil creates vicious cycles of limited catch up and 'falling behind' allows critical new insights.

Third, the South African case points to the need to include complementary analysis of the political dynamics shaping economic conditions, if lock-ins are to be broken. Typically, the policies and strategies to break the lock-in of a middle income trap identified from analysis of the East Asian economies include a strongly capacitated state, education and training, savings and investment, infrastructure, innovation and $\mathrm{R} \& \mathrm{D}$, and possibly, targeted industrial policy (Lee 2009; 2013 Lee and Kim 2009; Fu et al. 2010; Duran 2019; Wong and Fung 2019; Yasar 2019). These remain critical - but, the paper draws on the concept of 'upgrading coalitions', on the premise that to achieve these conditions requires sophisticated institutional arrangements and coordinated policies (Doner and Schneider 2016). And, the paper will argue, the conditions of inequality in a country like South Africa make it difficult to build the requisite institutional arrangements that can break the lock-in.

Through analysis of the case of South Africa using these conceptual tools, the paper aims to add to the literature on catch-up. It begins by showing that South Africa may be categorised as a country stalled in a middle income trap, and section 2 analyses data on the distinctive nature of the lock-in over time. Section 3 reviews the literature on middle-income traps to develop the concepts for analysis in conditions of extreme inequality. Section 4 uses these concepts to analyse South Africa's stalled trajectory. Section 5 analyses one niche, around a global astronomy project, in which South Africa has positioned itself to take advantage of a 'window of opportunity', building on historically grown capabilities, promoted by local 'upgrading coalitions' operating in the national interest. Section 6 proposes that in a similar manner, a 'detour' to build domestic capabilities could be driven by an upgrading coalition centred around local economic development and livelihoods in the informal economy. In this way, the paper aims to reinforce the evidence on how inequality is both a cause and consequence of a middle income trap, and open debate on how upgrading coalitions may be a critical strategy for breaking lock-ins. 


\section{South Africa stalled in a middle income trap}

\section{A long history of relative underperformance reflecting a stalled de- velopment trajectory}

South Africa features extensively as an empirical example in the literature on middle income traps. In fact, Doner and Schneider (2016) show that nine countries - Brazil, Mexico, Argentina, Colombia, Peru, Thailand, Malaysia, South Africa and Turkey - account for two-thirds of people living in middle income countries. This section considers the economic evidence over time, to illustrate South Africa's stalled development trajectory.

South Africa has been characterised as a highly unequal, dual economy, with a consumption expenditure Gini coefficient of 0.63 in 2015, the highest in the world (Stats SA 2018). The already high GINI coefficient, unlike a range of comparator countries such as Brazil or Malaysia, has increased since the mid-2000s. Understanding how inequality and income concentration shapes and is shaped by the development trajectory is therefore critical.

Like other middle income countries, GDP per capita has grown, from 410 USD in 1957, to 6,509.037 USD in 2018. However, Lee (2019) shows that per capita income levels as a percentage of the USA in South Africa have declined sharply, from around $37 \%$ in 1980, to $23.3 \%$ in 1995. Thereafter, they remained stuck around this level, for example, recorded as $23.6 \%$ in 2015. Similarly, drawing on World Bank data to calculate a ratio of GDP per capita in a country relative to the US (Y), Albuquerque (2019) shows that South Africa, like Brazil, is trapped between a Y value of 0.2 and 0.3 , since 1991.

Felipe et al. (2017) provide another set of measures that reflect the same stalled trend. They reject the concept of a middle-income trap, and instead, devise a methodology and dataset to trace the relative rate of transition from middle to high-income country status. They find that the median number of years countries take to traverse from lower-middle to highermiddle income status is 55. Only 10 economies were slower than this median rate in 2013, including South Africa. South Africa became a lower middle income economy in 1950, which in 2020, means 71 years. The average growth rate in South Africa over the period was $1.17 \%$, whereas benchmark calculations suggest that to transition to higher middle-income status, the growth rate should be closer to $2.3 \%$ per year. 
Figure 1 zooms in to reflect the longitudinal GDP growth data for South Africa since the 1960s. Despite a few peaks and troughs, which may be related to periods of intense political instability, GDP growth has progressively slowed down and declined, since the mid-1980s, with a further decline after the global recession of 2008.

\section{Figure 1 South Africa real GDP growth March 1961 to December 2018}

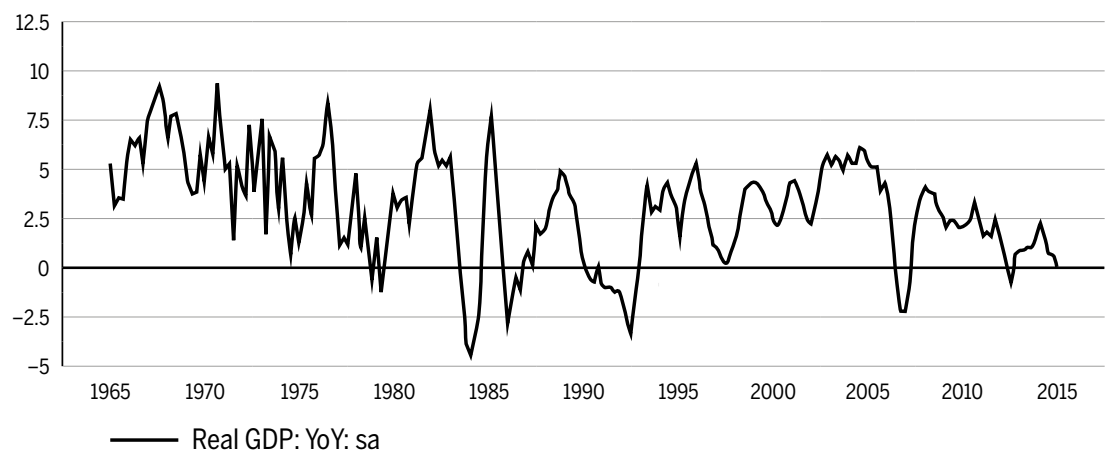

Source: Extracted by author from CEIC (2020).

Insights to interpret this trajectory are available from an emergent South African literature using the middle income trap framework as a tool of analysis to propose economic policy options. Fedderke (2018) for example, shows that South Africa lagged all comparator groups in its ability to grow, and shows signs of 'secular stagnation' due to long standing structural constraints. Bhorat et al. (2014: 31) characterise South Africa as a case of a 'low level economic growth trap' that is unable to achieve the 'strong redistributive outcomes and employment gains' required.

Luiz (2016: 51) describes South Africa as a typical case of a country with 'increasing deindustrialisation and a growth slowdown... that is unable to transition to higher value activities and manoeuvre through the complex product value chains necessitated by changing patterns of development and new competitive pressures'. He tracks GDP per capita growth back to 1700, to illustrate how South Africa diverged from comparator countries (Luiz 2016). It is evident in Figure 2 that South Africa under-performs relative to a set of high and middle income countries, but what Luiz shows is how this underperformance has lasted for an even more protracted period than suggested by Felipe et al. (2017), Albuquerque (2019) and Lee (2019). South Afri- 
ca initially outperformed Brazil until the end of World War II, but then began a process of relative slowdown and underperformed relative to comparator countries, even during its own high growth phases in the 1950s and 1960s.

Figure 2 South Africa's protracted slowdown: per capita GDP 1800 till 2010 (in 1990 Int. GK\$)

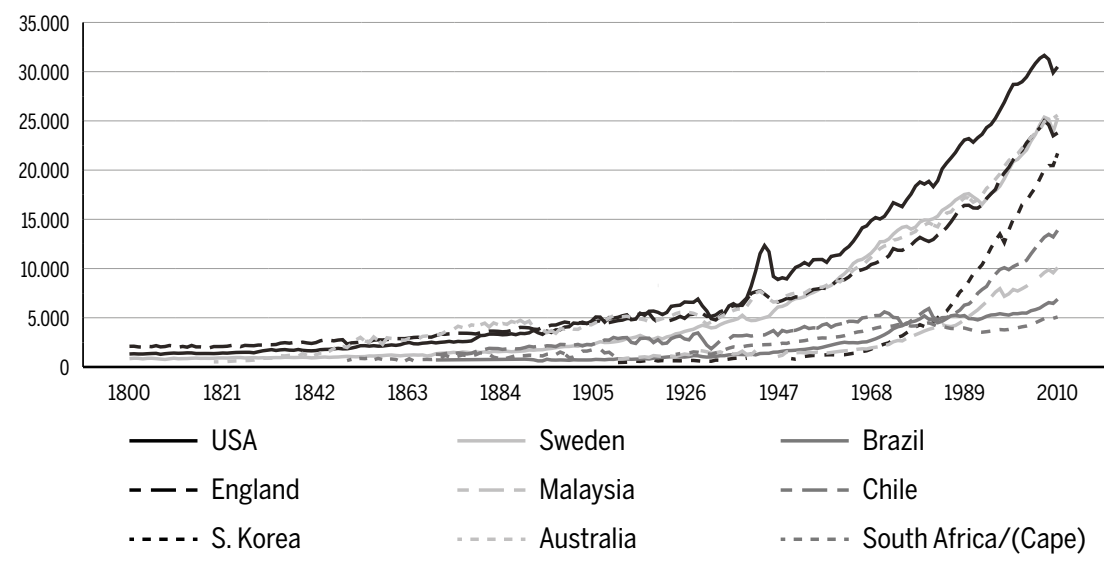

Source: Adapted from Luiz (2016).

Over the long range, South Africa reflects the stalled development trajectory of a middle income development trap, but the trajectory is tending towards a further decline in GDP per capita.

\section{The risk of falling behind?}

If a country in a middle income trap is by definition neither falling behind nor catching up (Lee 2013; Albuquerque 2019), the question remains whether South Africa should more accurately be interpreted as displaying a development trajectory of 'falling behind'. The evidence is not yet clear enough to make a call, given the global economic slowdown, but there are more negative signs recently, and, the economic devastation of the COVID 19 pandemic that erupted in South Africa in March 2020 will exacerbate these trends.

Since 2015, South African growth has stalled at very low levels, below $2 \%$, with a projected GDP growth rate for 2019 of $1.3 \%$, and for 2020 of 
$1.8 \%$, a slight improvement on the $0.8 \%$ achieved in 2018 . South Africa is currently among the worst economic performers in sub-Saharan Africa, with GDP growth of $0.5 \%$ predicted for 2019 (National Treasury 2019).

The domestic economy suffered a $3.2 \%$ contraction of real GDP growth in the first quarter of 2019.

Economists expected severe load-shedding and the five-month mining strike to have hurt the economy in the first quarter, but underestimated how weak the consumer and overall business environment had become, as well as the chilling effect that low confidence continues to have on fixed investment (Bisseker 2019).

The contraction increased unemployment, which stood at $27.1 \%$ in the first quarter of 2019, with a labour force participation rate of $59.3 \%$, and an unemployment rate for young people aged $15-24$ of $55.2 \%$ (StatsSA 2019).

The question is whether this is once again a period of 'limited falling behind' as identified by Albuquerque (2019), which is likely to be followed by another period of 'limited catching up' - or whether it reflects a longer term 'falling behind' trajectory. The prospect of a 'falling behind' trajectory is real, and creates greater urgency for interventions to break a potentially downward cycle. The length of time South Africa has stalled in the middle income trap suggests that the challenges of breaking lockins are significant.

\section{Transition from a middle income trap in conditions of intense inequality: the literature}

Economic catch-up is difficult, but if it is to be achieved, it is an art (Lee 2019). Drawing on the experience of successful Asian economies, Lee's most recent work (2019) develops a model for latecomer countries to escape the development trap:

- they must take a development path that differs from the forerunner countries;

- they should take a 'detour' to reach targets faster than competitor countries;

- they can attempt a high risk 'leapfrogging' through a window of opportunity;

- but only if they have built up the necessary capabilities through the experience gained in the 'detours'. 
The South African context is developmentally very different from East Asian countries (Swilling et al. 2015), so analytical frameworks must be adopted with caution, if they are not to lead to aspirational solutions and policy prescriptions that do not take what it is possible sufficiently into account, given vastly different threshold conditions.

The rapidly growing economic and political literature on 'middle income traps' can offer more fine-grained tools of analysis. Here, the main trend of debate is how to define a middle-income trap theoretically and empirically, considering whether it actually exists, and if yes, what the core features are and which countries are to be included empirically (Agenor, 2017; Glawe and Wagner, 2016; Ye and Robertson, 2016; Bulman et al. 2017; Pruchnik and Zowczak 2017). Agenor (2017: 785) defines a middle income trap simply as a 'bad but stable equilibrium to which a country may gravitate as a result of different initial conditions'. Ye and Robertson (2016: 173) develop a stricter definition and empirical test, whereby a country's 'growth rate has prematurely converged despite its income level being beyond the world frontier'.

This literature is useful for classification purposes, and for concluding with confidence that South Africa is locked in to a middle income trap, as demonstrated in Section 2. However, it does not provide analytical tools to assess how and why a specific country is stalled, in order to identify appropriate strategic policy choices.

Here Albuquerque (2019) provides useful conceptual direction, based on analysis in the Brazilian context, which has a comparable trajectory to that of South Africa. Like Lee, Albuquerque's work is located firmly within the innovation studies tradition (Nelson 1993), which assumes that central to the catch-up process is the formation of innovation systems:

[...] the outcome of structural change involving educational investments, industrial and technological policies, the formation and development of local firms, and investment in scientific infrastructure (Albuquerque 2019: 31).

In countries like South Africa and Brazil, which were colonised and incorporated into the global economy as subsidiaries of the European powers, building innovation systems relies largely on building domestic capabilities to imitate and absorb foreign technologies, and internalise new products and processes at the technology frontier. Critical to catch up is to ensure that these capabilities diffuse through the entire economy, and in relation to local conditions and resources. 
Albuquerque (2019) traces distinct alternating periods of catching up and falling behind in Brazil, driven by the intersection between developments in the forerunner economies globally, and the structural economic dynamics internal to the country. He argues that 'the limitations of catchup policies and new problems related to changes in the domestic economy may trigger crises that interrupt growth trajectories' (Alburquerque 2019: 32) and lead to periods of limited falling behind.

In trying to explain the Brazilian pattern, of alternating cycles of catchup and falling behind, he finds that inequality is at the heart of a middle income trap, because income concentration:

[...] exhausts energies of catching-up processes by blocking the formation of a huge domestic market as a source of economies of scale and scope for dynamic firms, and blocking the maturing of innovation systems extremely dependent on educational and scientific institutions to feed the catching-up processes (Albuquerque 2019: 53).

Inequality is thus both a cause and a consequence of the middle income trap. For example, income inequalities limit access to education, skills and science and technology resources, which in turn, places limits on the country's capability to enter more sophisticated high-level industries and value chains.

Albuquerque argues that income concentration shapes four vicious cycles in the Brazilian case that lead to 'permanent technological backwardness':

a) Limitations on the growth of domestic markets and the size of consumer markets;

b) Lock-ins to natural resources and less developed industries behind the technology frontier;

c) 'Predatory' innovation dynamics around control and use of natural resources, rather than industrial investment and 'innovative economic dynamics';

d) Political tensions and crises that provoke social and economic stalemates that block periods of limited catch-up.

Lock-ins arise from perpetually absorbing existing foreign technologies and never building the capabilities to 'leapfrog' using frontier technologies ahead of competitors, as Lee (2019) proposed to explain the success of East Asian countries. The policy challenge that Albuquerque (2019: 54) poses is 'how to transform those four vicious cycles that cause the alteration between catching-up and falling-behind periods, into positive periods that preserve the catching up process'? 
There are many pointers in the literature on economic catch-up. For example, Lee and Kim (2009) conducted econometric studies to show that new policy variables such as technology and tertiary education, as well as institutions, matter as the determinants of long-run economic growth. In a comparison of East Asian and Latin American experiences, Cardoza (1997: 388) proposed that while the literature may agree on the set of factors that played a role in East Asian development, more attention is required to 'the complex connections established between the multiple variables involved, at the micro and macro-economic levels', in order to create virtuous cycles of learning, innovation and growth.

Therefore, other approaches are needed to show how combinations of these factors matter in different contexts, and where the spaces for intervention may lie. Given the deeply politicised nature of these 'vicious cycles' driven by inequality, to find solutions it is necessary to go beyond an economic perspective, to include analysis of the political dimensions shaping innovation capabilities. Here the work of Doner and Schneider (2016) - political scientists who argue that there is a gap in the literature on middle income traps - appears fruitful. They point out that each of the polices typically proposed for catch-up, such as growing new industries, or building education and skills or scientific infrastructure, are not easy to implement, and require increasingly sophisticated institutional arrangements. Key actors need to coordinate resources and activities to achieve these institutional arrangements. As Doner and Schneider (2016: 610) ask 'Why would self-interested political and economic elites expend scarce resources to construct the complex institutions required to implement initiatives in areas such as technical education and R\&D?' They argue that in the current global context, breaking a lock-in is so much more difficult than in the past, because the policy solutions themselves are institutionintensive, and require what they call 'strong upgrading coalitions'. These coalitions need to succeed in the face of highly fragmented social and economic groups, whose competing interests must be reconciled:

What makes exiting the trap difficult is the institution-intensive nature of the required policy solutions combined with weak societal demand for such institutions (Doner and Schneider 2016: 611).

Their approach prompts a stronger analytical focus on the 'upgrading coalitions' required for institution-building to break the lock-ins of the middle income trap. Such a focus matches conceptually with the innovation 
systems literature's identification of key innovation actors with distinct purposes, the institutions and capabilities that promote interaction and alignment, and the building of networks for horizontal and vertical coordination to reach shared developmental goals (Von Tunzelmann 2010; Von Tunzelmann et al. 2010).

The following sections investigate how South Africa can break the lockins of the middle income trap. The analysis uses Albuquerque's model of the vicious cycles arising from inequality and income concentration, together with Doner and Schneider's concept of the 'upgrading coalitions' that may be present or absent, to reinforce or challenge these vicious cycles.

\section{How do the vicious cycles arising from inequality play out in South Africa?}

\section{Lock-ins to natural resources and less developed industries behind the technology frontier}

The South African economy is strongly shaped by its disadvantaged insertion into the global economy, beginning in the colonial period from the late nineteenth century with the exploitation and export of mineral resources (gold and diamonds, but later, a range of precious metals), accompanied by the development of upstream capital-intensive industries (Maharajh 2016; Scerri 2016).

From 1948 until the early 1990s, the economy was driven by the apartheid government's policy interventions in the face of global sanctions, to the benefit of a racially defined elite. The goal of growth and innovation was to promote self-sufficiency in fields such as mining, agriculture, energy and telecommunications.

After 1994, with a democratic dispensation and stronger global integration, the policy goal was significant structural transformation in the South African domestic economy, and a commitment to promote science, technology and innovation-driven growth to the benefit of all citizens. During this period, the patterns of unequal insertion into the global economy, and the weaknesses of the domestic economy, given its extractive nature and structure, seem to have deepened historic patterns of inequality and income concentration. Swilling et al. (2015: 2) criticise the current South 
African state for adopting a strategy of "non-developmental welfarism to address inequalities using fiscal policy, accommodating the mineral-energy complex rather than promoting secondary industrialisation, and promoting financialisation'.

These trends are evident in the changing structure of the formal South African economy over the past 25 years - the services sector has increased its share of GDP from $56.2 \%$ in 1993 to $62.7 \%$ in 2015 (Statistics South Africa 2017), while the share of both mining (from 15\% in 1993 to $7.3 \%$ in 2016) and manufacturing (from $14.3 \%$ in 1993 to $12.5 \%$ in 2016 ) have declined, and agriculture accounts for a small $2.5 \%$ of GDP in 2016.

Employment in services has grown to $71.08 \%$ in 2017, while employment in manufacturing declined to $23 \%$ in 2012 , where it has remained. Likewise, employment in agriculture stood at $8.83 \%$ in 2007 but has hovered around $4-5 \%$ thereafter ${ }^{1}$.

Makgetla (2013) argues that the structural change of the economy was most strongly driven by rapid financialisation accompanying the opening up to the global economy. This new global insertion had a negative impact on local development, as South Africa became a target market for shortterm capital flows. Figure 3 reflects the growth in foreign investment, in terms of the foreign portfolio holdings as a percentage of GDP.

The disproportionate growth in these flows meant that in some ways the country resembled an off-shore banking centre - not as a location for long-term deposits, but as a place for institutional investors to park excess liquidity (Makgetla 2013: 2).

The distinctive nature of foreign direct investment meant that the South African currency tended to be overvalued and volatile, creating negative conditions for domestic industries attempting to grow exports, particularly those that faced growing competition from cheap imports, such as clothing and textiles. The global financial crisis since 2008 exacerbated these dynamics, leading to a recession because of the contraction of export markets, and the reduction in mineral rents. There is an over-dependence on resource-based foreign exchange for export revenues and short-term growth (Bhorat et al. 2014). The pattern is typical of the vicious cycle elaborated by Albuquerque in Brazil - the lock-in of the domestic economy to the historical reliance on natural resources, and to growing financialisa1 https://www.statista.com/statistics/578944/employment-by-economic-sector-in-southafrica/. 
tion, with less developed industries behind the technology frontier that are not able to be globally competitive as a result.

Figure 3 Foreign portfolio holdings in South Africa as a percentage of GDP, 1979 to 2010

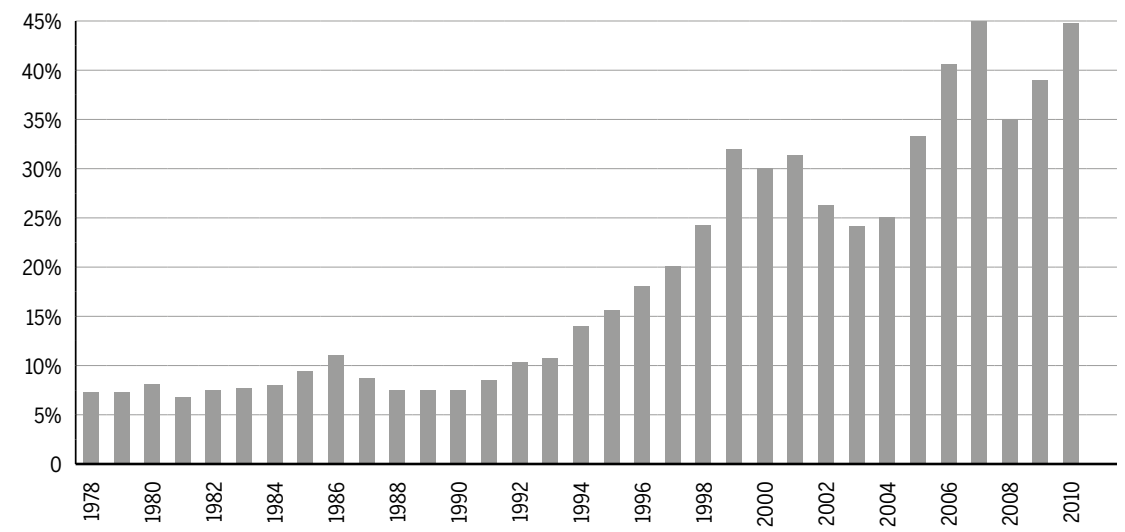

Source: Makgetla 2013. (Calculated from South African Reserve Bank interactive data series for total portfolio investment and GDP, downloaded from www.resbank.gov.za in August 2013).

\section{Limitations on the growth of domestic markets and the size of con- sumer markets}

These trends lead to lower levels of, and a reduced climate for. local investment, slower diversification of the economy into more productive sectors, slower employment creation in domestic industries, and larger outflows of resources, that perpetuate the vicious cycle. So, while the South African financial sector grew, it did not create direct employment on a large scale, it is concentrated in major metropolitan areas, such as Johannesburg and Cape Town, and it deepened inequality by paying high wages to a small pool of highly skilled senior managers (Makgetla 2013). Where employment creation did take place, it was focused on non-tradeable services, mostly to meet demand by the small high-income group, and disproportionately in security services (Makgetla 2013). Most analysts highlight the growing bias towards skills-intensive employment, driven by technological change, but this is severely constrained by the lack of high level skills, leading to a skills mismatch (Bhorat et al. 2015), 
which in turn, deepens unemployment, and limits the diffusion of innovation across sectors and firms.

A major cause of lock-in is therefore that the South African growth path was built on sectors that are not employment-intensive (Bhorat et al. 2014), with a trend of

$[\ldots] j o b$ destruction in the primary sectors, a manufacturing sector that has been ineffective as a generator of large-scale jobs, and a tertiary sector that has stepped in to fill this vacuum (Bhorat et al. 2015: 11).

Increasingly, there has been a reliance on state infrastructure for domestic growth (Bhorat et al. 2014), reflected in an expansion of employment in the public sector, the largest proportion of the community, social and personal services sector that together with the financial and business services sector accounts for the lion's share of total employment shifts (Bhorat et al. 2015).

Such a growth trajectory leads to high levels of market concentration, and high barriers to entry for new domestic firms in South Africa. Aterido et al. (2019) reflect on how barriers to entry distort market structure, reduce incentives for productivity and innovation, and limit firm dynamism. Their analysis of South African firm level data shows that large, and well established firms - rather than new firms - are creating jobs, and mainly in the services sector. Moreover, they find a decline in productivity growth over time, and that productivity gains are likely achieved at the expense of cutting jobs and reducing labour, rather than through innovation. This they attribute to low levels of exports, but significantly, also to weak demand from domestic markets. The evidence suggests a poor quality, inefficient system that hampers knowledge transfers and increases the cost of doing business (Bhorat et al. 2014), making it difficult for new firms to enter domestic markets.

As Doner and Schneider (2016) argue, large concentrated business groups wield political power to entrench their own narrow short-term interests, rather than supporting policies that may assist the economy to break out of the middle income trap. The situation is exacerbated by the inadequacies of black economic empowerment policies that were introduced in South Africa in an attempt to redress inequality, but that have transferred ownership and control to a new political elite that focus on consumption, rather than an investment driven growth trajectory (Bhorat et al. 2014).

The size and growth of South African domestic markets are constrained by high levels of unemployment and poverty, which is unevenly distrib- 
uted, concentrated in sub-regions with the worst colonial and apartheid legacies. In 2019, approximately half of the adult population, 49,2\% were reportedly living below the upper-bound poverty line, spatially concentrated in the most historically under-developed regions, such as the predominantly rural and spatially isolated Limpopo province $(67,5 \%)$, in contrast to the economically strongest and most developed province, Gauteng $(29,3 \%)$.

One of the conditions that make poverty and formal unemployment in South Africa such a constraint is that historically, the processes of creating a labour force for the mining industry in the colonial period involved dispossession of land and the large-scale destruction of subsistence and small-holder farming in the rural areas (Makgetla 2019). In the urban areas, African people were forced to live in racially defined 'townships' with little formal economic opportunity. The informal economy is smaller than in many other African countries such as Nigeria or Ghana (Jegede 2020), and has taken the form of largely 'survivalist', very micro-enterprises operating in a very localised manner, reflecting a gap in opportunities for self-employment.

\section{State capacity, state capture and predatory innovation dynamics}

Doner and Schneider (2016) argue that in today's middle income countries, strong and effective upgrading coalitions are not able to emerge. The social cleavages resulting from growing inequality do not support - and may indeed block - collective action and coalition building. They cite many historical cases where such coalitions

[...]facilitated inter-temporal bargains needed for investing in those upgradingrelated investments that required extensive information, negotiation, monitoring and short-term costs, but whose benefits would emerge only in the medium or long term (2016: 619).

They point to a trend in countries like South Africa, Brazil, Malaysia or Turkey, where the state and political parties are driven by short-term interests and unlikely to form upgrading coalitions, becoming increasingly populist, corrupt or driven by clientelist politics.

South Africa after 1994 adopted the model of a developmental state, and at least aspired to strong upgrading coalitions (see Schneider 2015 for 
comparative analysis of the Brazilian case). A number of institutional arrangements that attempted to balance the interests of state, private sector, labour and community organisations were created, such as a National Economic Development and Labour Council (NEDLAC). There were some early successes, peaking in economic and social performance in 2007 (Edigejhi 2010; Gumede 2009). However, recent assessments are that the developmental state has failed (Swilling et al. 2015), and that South Africa 'is now a fragile state, expected to continue to weaken' (Sgauzzin 2019).

Swilling et al. (2015) argue that the basic power structures of the apartheid socio-political regime were essentially left intact, so that the new democratic state included new black elites in political power, but protected the groups historically controlling economic power. The result has been predatory economics in the form of rent-seeking by black elites formerly excluded from political and economic power, acting in their own narrow interests, in coalition with existing (largely white) economic elites. Bhorat et al. (2014) show how regulation has been used to distort domestic markets to extract rents in favour of certain stakeholders. Such clientelism thrives in conditions of poverty and inequality (Doner and Schneider 2016).

Luiz (2016: 17) argued that the state escaped 'absolute capture as it appeases both ends of the spectrum'. That is, the state addressed the interests of the most vulnerable and marginalised social strata through social spending and cash transfers. Or as Swilling et al. (2015) claim, "non-developmental welfarism' was implemented on a massive scale to prevent popular unrest. At the same time, the state addressed the interests of the upper strata, by perpetuating the economic status quo. Luiz (2016) therefore characterised South Africa as displaying a 'bounded populism', echoing Doner and Schneider (2016) by arguing that this 'sacrifices innovation with an elaborate rent-granting system while retaining economic stability, be it at a low level'. In Doner and Schneider's terms, these short-term political interests blocked coalition-building that could support investment in upgrading-related investments. Such populism can lead to unsustainable redistribution that addresses political discontent, but serves to further undermine institutions and capacity building.

These dynamics are summed up by the scourge of 'state capture' in South Africa, the illicit exploitation of public funds for private gain. Chipkin et al. (2018) reveal the sophisticated systems and functioning of the rent-seeking, 'shadow state' that took hold after 2009, arguing that it 
formed coalitions that display the coordination and integration of skills akin to those of a multi-national corporation, but that operate to the narrow, short-term benefit of power elites:

\begin{abstract}
At the outset, control must be established over the sources of extraction, including the ability to respond flexibly to any changes in the operating environment. Once access to the source of extraction is secured, networks of middlemen or brokers must be established that can move resources externally, usually transnationally, to sustain loyalty (this is critical to ensuring the survival of the networks). The ability to transact within this network is facilitated by establishing political marketplaces where support is traded through the provision of access to resources (Chipkin et al. 2018: 19).
\end{abstract}

The depth of the patronage networks of the 'shadow state' (see Olver 2017 for analysis at the metropolitan level), the degree of centralisation of extraction and control of rents under the leadership of Jacob Zuma, the former president of South Africa, between 2009 and 2018, and the lucrative advantages for corporate elites in the banking, accounting and legal sectors (Marchant et al. 2020; Habiyaremye and Raymond 2018) served to further weaken domestic markets - and contribute significantly to the current cycle of 'falling behind'. 'State capture' has a direct impact on economic conditions. The procurement spend of the state owned enterprises responsible for energy and transport, for example, were captured into extractive patronage networks, which negatively impact on the infrastructures essential to routine business operations, as well as daily life conditions for citizens.

The wider impact of such rent-seeking and corrupt coalition building on the growth trajectory over the past decade is considerable: it destroys public trust, which undermines tax compliance, which limits the resources of the state; it undermines and hollows out the capacity of state and other economic actors for driving development agendas; it generally erodes confidence in the economy, limiting foreign investment and leading to flights of capital and skills; and it redirects surpluses away from productive employment-generating investments - and from upgrading coalitions and the policies required for innovation.

In short, the state institutions to coordinate, monitor and reconcile the interests of multiple groups have been captured to the short term, extractive benefit of old and new political elites. The deep inequalities and social cleavages in South Africa make politics vulnerable to elite capture and clientelism, which in turn, blocks the emergence and allocation of state resources to 'effective upgrading coalitions'. 


\section{The vicious cycle of lock-in arising from a lack of skills and capability} building

Catch up has historically been accompanied by improvements in the educational levels of a country, and the capacity to build high-level skills (Lee 2009; Lee and Kim 2009; Wong and Fung 2019). Inequality in access to education, training and skills development is a major constraint on the ability to alleviate poverty and unemployment, and hence, to transition from the middle income trap (Albuquerque 2019). As Albuquerque argues, the persistence of income concentration limits universal access to high quality public education, which in turn, constrains science and technology dynamics.

The evidence suggests that South Africa spends sufficiently on both basic education ( $6.1 \%$ of GDP) and on post-school education and training, but its performance relative to its comparator peers is weak. The problem at the level of basic education is critical, where threshold conditions for success in post-school education and training are not being created. A recent World Bank Human Capital Index found that a child born in South Africa currently is only $41 \%$ as productive as they could be, if health and schooling systems were operating as they should be (World Bank, 2020). While South Africa has achieved universal access, on average, a child who starts school at the age of 4 can expect to have completed 9.3 years of schooling, which is below comparator countries. Learning outcomes are poor, due to the poor quality of schooling, and the requirement to learn in English rather than mother tongue language, which reduces the effective average years of schooling to 5.1 years. Underperformance is strongly associated with, and shaped by, historical patterns of inequality.

These educational quality weaknesses impact on economic activity. For example, in 2013, a high $33 \%$ of the unemployed had completed a secondary school qualification, an increase from $17.5 \%$ in 1994 , which is an indication that significant cohorts of young people have not built the skills required in the workplace during their schooling (Bhorat et al. 2015). Skills mismatch exacerbates the vicious cycle - not only whether young people are able to access education and training institutions, or whether they are able to obtain the desired qualifications, but whether they are learning the right kinds of skills required for innovation and economic development (Kruss et al. 2019). 
These conditions shape institutional dynamics in the higher education system, which is so critical to innovation, growth and economic development (Geuna and Rossi 2015). Inequality continues to create a fetter on high-skills capacity building, determining who will have access to, and who will successfully traverse the higher education and training system, and into employment (Rogan et al. 2019; Swartz et al. 2018). In an unequal, sharply differentiated higher education landscape and a formal economy with weak absorptive capacity, higher education is constrained from delivering on its mandate of social mobility and inclusivity (Bank and Kruss 2019). The absence of an upgrading coalition between university management, student government and business - and instead, the presence of active contestation (Jansen 2017; Habib 2019) - is a constraint on ensuring the scale and quality of skills to support innovation and grow technological capabilities.

\section{Breaking the lock-ins?}

The protracted lock-in and inability to transition from middle income status in South Africa is determined by the interplay between these vicious cycles. South Africa shares with Brazil the lock-ins to natural resources and less developed industries behind the technology frontier, and has more intensive limitations on the growth of domestic markets and the size of consumer markets. It has its own version of predatory economic dynamics, in the form of a decade of 'state capture' and hollowing out of state capacity, which creates political tensions and crises that make it difficult to gain support from social and economic actors to forge technological upgrading coalitions, and undermines the framework conditions for catchup, such as energy. In South Africa, significantly, income concentration and inequality are both cause and consequence of a vicious cycle of lock-in around education, skills and capability building that fetter technological upgrading. The outcome of these vicious cycles, as Albuquerque (2019) argues in the Brazilian case 'is permanent technological backwardness', and an inability to break out of the middle income trap.

Using the political lens proposed by Doner and Schneider (2016) highlights how the tendency to fall behind is associated with a failure to build the required institutions through forging developmental upgrading coalitions, and hence, this points to a potential mechanism for change. The 
next section will go on to reflect on potential moments of catch-up, in an attempt to identify what may be possible, if South Africa is transform away from technological 'backwardness'.

\section{Islands of excellence - what could technological upgrading coalitions look like? ${ }^{2}$}

In terms of science, technology and innovation, South Africa generally falls behind its comparator countries, but there are islands of excellence in which it is abreast of, or even potentially expanding, the technology frontier. This section analyses one niche in which South Africa attempts to 'leapfrog' by taking advantage of a high risk 'window of opportunity' (Lee 2019), building on historically grown capabilities that have been promoted by local technological 'upgrading coalitions' operating in the interests of catch up. The question is whether such a big science project can provide an opportunity to 'leapfrog', or whether the vicious cycles will lock in the attempt, leading to a cycle of 'falling behind'.

The Square Kilometre Array (SKA), a giant radio telescope, will become the largest science installation ever undertaken in Africa, but the SKA organisation, which includes Australia, Canada, China, Germany, India, Italy, the Netherlands, Poland, South Africa, Sweden, and the United Kingdom, is headquartered in the UK. The SKA is effectively a hub for multiple global innovation networks, which requires advanced capabilities to operate effectively. For example, because ICTs are constantly and rapidly advancing, the SKA needs to be able to forecast technological changes, which requires networks with major global firms such as Intel and IBM, as well as building local capabilities.

In 2003 South Africa, together with its African partner countries, entered a bid to host the site infrastructure, based on excellent natural conditions for astronomy and on existing astronomy capabilities. From 2003 to 2012, a South African SKA project office worked to develop skills and technologies in support of this bid, in the process developing a prototype set of seven receiver dishes, the KAT-7, and beginning construction of a 64-dish instrument, the MeerKAT. The SKA organisation in South Africa 
built a successful upgrading coalition, by establishing formal and informal mechanisms to bolster the development of the required radio astronomy, ICT and engineering skills (breaking the vicious cycle for these innovation systems), and to ensure alignment with a wide range of private and public actors relevant to these global innovation systems. The shared goal was to coordinate pockets of excellence to build up technological capabilities to make South Africa internationally competitive against a rival bid from Australia and New Zealand. Strong political will was reflected in high-level support by the state and policy makers, in the form of increased levels of funding and promotion of the SKA (Gastrow et al. 2016). The strategy of building local technological capabilities to leverage geographic advantage was successful, in that the majority of the project was allocated to South Africa and its African partner countries.

The SKA case illustrates that by building on long established scientific and technological capabilities, and harnessing capability to forge upgrading coalition, South Africa is able to take advantage of a "window of opportunity'. However, early indications are that it has limited reach in terms of creating large-scale employment, alleviating poverty, or diffusing technological capabilities through the economy. Moreover, the potential that the SKA project could widen inequality is high, even in the local areas in which the telescope array is based (Gastrow and Oppelt 2019). Such a sciencedriven 'window of opportunity' may not be sufficient to contribute to break the middle income trap in a significant manner, in that it does not transform the income concentration and inequality at the heart of the vicious cycles.

\section{A new kind of detour: building an upgrading coali- tion around livelihoods in the informal sector}

Lee (2019) also proposes that in enacting the art of catch-up, a country could take a 'detour' to build capabilities in a technology behind the frontier that can later enable it to break out of the middle income/ trap and move onto a catching up trajectory. The question is - what could be the focus of a 'detour' to be promoted by an upgrading coalition in South Africa? What could drive economic restructuring in an employment generating and poverty- reducing manner that can decrease the inequality driving vicious cycles of 'falling behind'? 
The debate around industrial policy typically centres on picking 'winners', on identifying that almost magical set of technologies or sectoral niches that could give a country the edge against its comparators to stimulate competitiveness and growth. The catch-up literature presents many cases of how this has worked, in relation to electronics, ICTs, and so on. Section 5 analysed how a frontier technology like the SKA is limited in its ability to provide such a 'window of opportunity'.

Section 6 offers a more radical proposal for a 'detour' that directly addresses and potentially takes advantage of the domestic inequality and unevenness of economic development in South Africa. The clue comes from the work of South African economists who essentially argue for the need to forge an 'upgrading coalition' focused on:

Employment and livelihood creating investments across a wide spectrum of small and medium enterprises capable of absorbing large numbers of unskilled and semi-skilled workers...supported by a proliferation of innovations ... that connect knowledge and market opportunities with investment flows and an enabling regulatory environment (Chipkin et al. 2018: 137).

This would be a strategy akin to the typical catch-up detour of creating large-scale employment in low-skills occupations in manufacturing sectors. That trajectory is no longer a guaranteed catch-up route, given the decline of the formal domestic manufacturing sector in South Africa, very different global competitive dynamics, and the growing digitalisation of work in all sectors that require high-level skills.

Recent research shows how informal enterprises are starting to create employment and livelihoods on a large scale, in the informal sector, defined as 'the collection of income-generating activities and micro-enterprises that are producing legal goods largely outside state regulation' (Cozzens and Sutz 2014:6). In 2013, over 2,3 million people were employed in the informal sector, estimated to contribute around $5.9 \%$ to South Africa's GDP (StatsSA, 2013), and Fourie (2018) estimate that this had risen to 2.9 million in 2018. Significantly, the share of the workforce in the informal sector is highest in the poorest regions, those most historically undeveloped and with higher levels of poverty and unemployment, as described in Section 4. It is also higher in towns and cities other than the big metropolitan areas, such as Johannesburg, and higher amongst people living in traditional communal rural areas, in townships and informal settlements in urban areas (Fourie 2018).

Informal-sector employment has a significant impact on poverty reduction (Cichello and Rogan 2018), because income flows primarily to poor 
households. The critical difference is that unlike the formal economy, the average 'rand' circulates more often, and hence, stimulates the growth of local economies that reach more households and individuals. A critical 'window of opportunity' could therefore be to recognise the informal sector as a vital part of the economy that contributes to growth and development, and to develop and implement policies that can support its flourishing (Fourie 2018; Alcock 2018). If the state, private sector and civil society could align to promote more local economic development, and more livelihoods for more households, larger domestic markets for consumption could grow, which could generate a virtuous cycle.

In South Africa, such an orientation would not require a significant shift in formal state policy, but it would require reorienting the balance of the priorities of the national system of innovation in practice. South Africa has long committed to grow a national system of innovation that will promote dual goals of economic competitiveness and quality of life for all citizens (see Maharajh 2016). The new White Paper on Science, Technology and Innovation (DST 2019: 7) strengthens this dual goal through a renewed vision for STI 'enabling sustainable and inclusive development in a changing world', and promotes 'innovation that addresses the triple challenge of inequality, poverty and unemployment'. There are existing regulatory and policy initiatives that could be prioritised and resourced more effectively - if there were the political will and support, driven by an upgrading coalition. For instance, there is a policy thrust to promote small, medium and micro-enterprises (SMMEs), for linking the informal and formal economies and, most recently, for promoting employment and economic opportunities in the informal economy. A shift in government priorities was evident in the establishment of a national Department of Small Business Development (DSBD), dedicated to aligning the development of the SMME sector with the National Development Plan.

State policy and strategies in principle (Petersen and Kruss 2019) propose to target entrepreneurs in the informal economy based in townships, rural areas, and depressed areas in towns and cities, to provide assistance in the form of skills development, technology support, funding and equipment (Kraemer-Mbula 2016). A new institutional structure was proposed, with the aim to build an enabling environment to promote the potential to improve economic redistribution. Recently, policy instruments that promote innovation were created, with a focus on promoting technological 
upgrading, technology transfer and diffusion in SMMEs and informal enterprises in townships and rural areas. The challenge is to build a stronger upgrading coalition that drives such processes in practice.

A model of 'digital distributism' could inform such an upgrading coalition. The economic model of 'digital distributism' embodies the logic and values of earlier artisanal economies, but enabled and enhanced by new digital technology platforms:

Instead of simply digitising industrial extraction in the name of growing more capital, our new technologies can distribute value creation in the name of a sustainable economy (Rushkoff 2016: 229).

The challenge is to think of an economy that is able to see "an opportunity to participate in self-sustaining, highly reciprocal, peer to peer and worker owned and community-defined market places' (Rushkoff 2016: 225). Distributism calls for the widest possible distribution of the digital means of production itself - in which economic power is granted to 'the maximum number of the smallest possible nodes'. The existing SMME and innovation policy frameworks could provide a foundation for a model of building technological capabilities in the informal sector through such 'digital distributism'.

With a weakly capacitated state, and the prevalence of predatory innovation dynamics, the institutions to implement and support these distributive local economic policies are missing, so that existing policies have not yet made significant impact in breaking the vicious cycle of limited domestic markets. With a strong upgrading coalition that coordinates divergent interests, as was possible for the SKA case, a detour that aims to transform income concentration, and include more economic and social actors, could offer a potential trajectory to break historical lock-ins.

\section{Conclusion}

The policy challenge that Albuquerque (2019: 54) posed in Brazil applies to South Africa: 'how to transform those four vicious cycles that cause the alteration between catching-up and falling-behind periods, into positive periods that preserve the catching up process'?

The paper has tried to demonstrate, from analysis of the South African case, that in the current global context, breaking a lock-in is so much 
more difficult than in the past, because the policy solutions themselves are institution-intensive, and require strong upgrading coalitions. These coalitions need to succeed in the face of highly fragmented social and economic groups, whose competing interests must be reconciled, so that there is stronger societal demand for such institutions. If the political will, resources, institution and network building devoted to the success of frontier science initiatives like the SKA were harnessed into an upgrading coalition to build innovation in the informal economy, and in relation to livelihood generation for more households living in poverty with few prospects of employment, South Africa may have a better chance at a new kind of 'detour' that can promote a catch-up trajectory with economic benefits that are more equally distributed and inclusive.

Harnessing the national response to the disruption of the COVID pandemic in 2020, to reorient towards inclusive development goals, presents another opportunity for a 'detour' to break the lock-in. Early on, the state's response was exemplary, proposing a national strategy that in effect, was based on creating an 'upgrading coalition' to harness actors across the national system of innovation to respond to the global health pandemic. However, the initial promise of the 'upgrading coalition' is at risk, undermined by the vicious cycles typical of the middle income trap: political tensions and crises, and predatory innovation dynamics. It is too early to predict the outcome, but the challenges of COVID have thrown the need to break these vicious cycles into stark relief.

By extrapolating from the case of South Africa, how does the paper contribute to the literature on the growth and development strategies of middle-income countries in general? First, it confirms Lee's (2019) approach to study catch-up as an art, with diverse path-dependent windows of opportunity and detours. Second, it supports Albuquerque's (2019) emphasis on inequality and income concentration as drivers of vicious cycles and lock-ins, and hence, fetters on growth that reinforce a middle-income trap. Third, it promotes the significance of forging 'upgrading coalitions' (Doner and Schneider 2016) to create actively the institutional conditions required to break the lock-in of these vicious cycles. Finally, it proposes for further investigation and exploration, the potential of a model of 'digital distributism' (Rushkoff 2016) that can inform the formation of upgrading coalitions that promote the informal economy, as a new form of detour that may shift the middle-income trap. 


\section{References}

AGÉNOR, P. Caught in the middle? The economics of middle-income traps. Journal of Economic Surveys, v.31, i.3, pp. 771-791, 2017. Available at: http://10.0.4.87/joes.12175.

ALBUQUERQUE, E. Brazil and the Middle-Income Trap: Its Historical Roots. Seoul Journal of Economics, v.32, i.1, pp. 23-62, 2019.

ALCOCK, G.G. Kasinomic revolution. The rise of African informal economies. Bryanston: Tracey MacDonald Publishers, 2018.

ATERIDO, R.; HLATSHWAYO, A.; PIETERSE, D.; STEENKAMP, A. Firm dynamics, job outcomes and productivity. World Bank Group. Policy Research Working Paper. 8788. March, 2019.

BANK, L.; KRUSS, G. Beyond the campus gate: Higher education and place-based development in South Africa. In: SOUDIEN et al. Eds. State of the Nation: Poverty and Inequality. Cape Town: HSRC Press, 2019.

BHORAT, H.; CASSIM, A.; HIRSCH, A. Policy coordination and growth traps in a middle-income country setting: the case of South Africa. WIDER Working Paper, No, 155, 2014. Available at: http://hdl.handle.net/10419/108005.

BHORAT, H.; NAIDOO, K.; OOSTHUIZEN, M.; PILLAY, K. Demographic, employment, and wage trends in South Africa. No. wp-2015-141. World Institute for Development Economic Research (UNU-WIDER), 2015. DOI: https://doi.org/10.35188/UNU-WIDER/2015/030-0.

BISSEKER, C. GDP growth: shock and awe. Business Live Premium. June 06, 2019. Available at: https://www.businesslive.co.za/fm/fm-fox/2019-06-06-gdp-growth-shock-and-awe/.

BULMAN, D.; MAYA, E.; HA, N. Transitioning from low-income growth to high-income growthis there a middle income trap? World Bank Policy Research Working Paper No. 7104, 2014.

CARDOZA, G. Learning, innovation and growth: a comparative policy approach to East Asia and Latin America. Science and Public Policy, v.24, i.6, pp. 377-393, 1997.

CEIC. South Africa Real GDP Growth, 2020. Retrieved from https://www.ceicdata.com/en/ indicator/south-africa/real-gdp-growth.

CHIPKIN, I. SWILLING, M.; WITH BHORAT, H.; BUTHELEZI, M.; DUMA, S.; FRIEDENSTEIN, H.; MONDI, L.; PETER, C.; PRINS, N.; QOBO, M. The Shadow State. The politics of state capture. Johannesburg: Wits University Press, 2018.

CICHELLO, P.; ROGAN, M. Informal-sector employment and poverty reduction in South Africa: The contribution of 'informal' sources of income. In: FOURIE, F. Ed. 2018. The South African Informal Sector: Creating jobs, reducing poverty. Cape Town: HSRC Press, 2018.

COZZENS, S.; SUTZ, J. Innovation in informal settings: Reflections and proposals for a research agenda. Innovation and Development, v.4, i.1, pp. 5-31, 2014.

DST. Department of Science and Technology. White Paper on Science, Technology and Innovation. 2019. Available at: www.dst.gov.za. Accessed on May 03, 2019.

DONER, R. F.; SCHNEIDER, B. R. The Middle-Income Trap. World Politics, v.68, i.4, pp. 608644, 2016. DOI: http://dx.doi.org/10.1017/S0043887116000095.

DURAN, C. Globalization and the Scrambling Process of Catching Up in Mexico. Seoul Jour- 
nal of Economics, v.32, i.1, pp. 83-106, 2019.

EDIGEJHI, O. Constructing a developmental state in South Africa. Cape Town: HSRC Press, 2020.

FELIPE, J.; KUMAR, U.; GALOPE, R. Middle-income transitions: trap or myth? Journal of the Asia Pacific Economy, Routledge, v.22, i.3, pp. 429-453, 2017. DOI: http://10.0.4.56/13547 860.2016.1270253.

FOURIE, F. The South African Informal Sector: Creating jobs, reducing poverty. Cape Town: HSRC Press, 2018a.

FOURIE, F. Creating jobs, reducing poverty I: Why the informal sector should be taken seriously and enabled properly, 2018b. Available at: http://www.econ3x3.org/article/creating-jobsreducing-poverty-i-why-informal-sector-should-be-taken-seriously-and-enabled.

FU, X.; PIETROBELLI, C.; SOETE, L. The Role of Foreign Technology and Indigenous Innovation in Emerging Economies: Technological Change and Catching Up. Inter-American Development Bank. IDB-TN-166, 2010.

GASTROW, M.; KRUSS, G.; PETERSEN, I. H. Connecting capabilities in highly unequal developing countries: The case of the Square Kilometre Array telescope in South Africa. Development Southern Africa, v.33, i.3, pp. 361-375, 2016. Available at: http://www.tandfonline.com/doi/full/10.1080/0376835X.2016.1153455.

GASTROW, M.; OPPELT, T. The Square Kilometre Array and Local Development Mandates in the Karoo. Journal of Southern African Studies, v.45, i.4, 2019. DOI: https://doi.org/10.10 80/03057070.2019.1642679.

GILL, I.; KHARAS, H. An East Asian Renaissance: Ideas for Economic Growth. Washington: World Bank, 2007.

GILL, I.; KHARAS, H. The Middle-Income Trap Turns Ten. World Bank PRWP 7403, 2015.

GLAWE, L.; WAGNER, H. The Middle-Income Trap: Definitions, Theories and Countries Concerned-A Literature Survey. Comparative Economic Studies, v.58, i.4, pp. 507-538, 2016. DOI: http://dx.doi.org/10.1057/s41294-016-0014-0.

GUENA, A.; ROSSI, F. The university and the economy. Pathways to growth and economic development. Cheltenham: Edward Elgar, 2015.

GUMEDE, W. Delivering the democratic developmental state in South Africa. Development Planning Division working paper series, n. 9, 2009.

HABIB A. Rebels and rage: Reflecting on \#FeesMustFall. Johannesburg: Jonathan Ball, 2019.

HABIYAREMYE A, RAYMOND W. How do foreign firms' corruption practices affect innovation performance in host countries? Industry-level evidence from transition economies. Innovation, v.20, i.1, pp. 18-41, 2018.

JANSEN, J. As by fire. The end of the South African university. Cape Town: Tafelberg, 2017.

JEGEDE, O. O. Open development and scaling-up of clustered enterprises in Nigeria's informal sector. African Journal of Science, Technology, Innovation and Development, v. 12, i.6, 2020, pp. 689-698, 2020.

KRAEMER-MBULA, E. Informal innovations and the South African innovation system. In: SCERRI, M. The emergence of systems of innovation in (Southern) Africa: long histories and contemporary debates. Johannesburg: MISTRA, 2016. 
KRUSS, G.; WILDSCHUT, A.; PETERSEN, I. Skills for the future. New research perspectives. Cape Town: HSRC Press, 2019.

LEE, K.; KIM, B.Y. Both institutions and policies matter but differently for different income groups of countries: determinants of long-run economic growth revisited. World Development, v. 37, i. 3, pp. 533-549, 2009.

LEE, K. How Can Korea be a Role Model for Catch-up Development? A 'Capability-based View'. UNU-WIDER Research Paper No. 34, 2009.

LEE, K. Schumpeterian Analysis of Economic Catch-up: Knowledge, Path-creation, and the Middle income Trap. Cambridge: Cambridge University Press, 2013.

LEE, K. The art of economic catch-up: Barriers, detours and leapfrogging in innovation systems. Cambridge: Cambridge University Press, 2019.

LUIZ, J. M. The Political Economy of Middle-Income Traps: Is South Africa in a Long-Run Growth Trap? The Path to "Bounded Populism". South African Journal of Economics, v.84, i.1, pp. 3-19, 2016.

MAHARAJH, R. 2016. Towards the Next-generation Science and Technology White Paper for South Africa: Innovation for Transformative Change and Inclusive Development Situational Analysis. A Discussion Document of the National Advisory Council on Innovation, 2016. Available at: http://www.naci.org.za/wp-content/uploads/2010/01/Situational-Analysis. pdf.

MAKGETLA, N. Financialisation in South Africa: A discussion document. Pretoria: Department of Economic Development. UNDP and UNDESA, 2013.

MAKGETLA, N. Jobs malaise due to much more than just bad governance. Business Live Premium, May 28, 2019.

MARCHANT, M.; MOSIANA, M.; HOLDEN,, P.; VAN VUUREN, H. The Enablers: The bankers, accountants and lawyers that cashed in on state capture. Open secrets, 2020. Retrieved from www.opensecrets.org.za.

NATIONAL TREASURY. Medium-term budget statement. Pretoria, 2019. Available at: http:// www.treasury.gov.za/documents/mtbps/2019/2019\%20MTBPS\%20presentation.pdf.

NELSON, R. National Systems of Innovation. A comparative analysis. New York and Oxford: Oxford University Press, 1993.

OLVER, C. How to steal a City. The battle for Nelson Mandela Bay. An inside account. Cape Town: Jonathan Ball Publishers, 2017.

PETERSEN, I.; KRUSS, G. Promoting alignment between innovation policy and inclusive development in South Africa. Development Southern Africa, v.36, i.3, pp. 351-375, 2019.

PRUCHNIK, K.; ZOWCZAK, J. Middle-Income Trap: Review of the Conceptual Framework. ADBI Working Paper 760. Tokyo: Asian Development Bank Institute, 2017. Available at: https://www.adb.org/publications/middle-income-trap-mit-review-conceptual-framework.

ROGAN, M. Post-school education and the labour market in South Africa. Cape Town: HSRC Press, 2019.

RUSHKOFF, D. Throwing rocks at the Google bus: How growth became the enemy of prosper- 
ity. Penguin, 2016.

SCERRI, M. The emergence of systems of innovation in (Southern) Africa: long histories and contemporary debates. Johannesburg: MISTRA, 2016.

SCHNEIDER, B. The developmental state in Brazil: comparative and historical perspectives. Brazilian Journal of Political Economy, v.35, i.1, pp. 114-132, 2015.

SGUAZZIN, A. South Africa's Decline Is Worst Among Nations Not at War, Model Shows. Bloomberg, April 2019. Retrieved from: https://www.bloomberg.com/news/articles/2019-04-17/ south-africa-s-decline-worst-of-nations-not-at-war-model-shows.

STATSSA. South Africa poverty and inequality assessment report, 2018. Available at: http:// www.statssa.gov.za/wp-content/themes/umkhanyakude/documents/South_Africa_ Poverty_and_Inequality_Assessment_Report_2018.pdf.

STATSSA. Quarterly Labour Force Survey (OLFS), $1^{\text {st }}$ Quarter 2019. 2019. Available at: http:// www.statssa.gov.za/?p=12121.

SWILLING, M.; MUSANGO, J.; WAKEFORD, J. Developmental States and Sustainability Transitions: Prospects of a Just Transition in South Africa. Journal of Environmental Policy \& Planning, v.18, i.5, pp. 650-672, 2015. DOI: 10.1080/1523908X.2015.1107716.

SWARTZ, S.; MAHALI, A.; MOLETSANE, R.; AROGUNDADE, E.; KHALEMA, E.; COOPER, A.; GROENEWALD, C. Studying while black. Race, education and emancipation in South African universities. Cape Town: HSRC Press, 2018.

VON TUNZELMANN N. Alignment, misalignment and dynamic network-based capabilities. In: DA Dyker (Ed.) Network dynamics in emerging regions of Europe. London: Imperial College Press, 2010.

VON TUNZELMANN, N.; GUNTHER, J.; WILDE, K; JINDRA, B. Interactive dynamic capabilities and regenerating the East German innovation system. Political Economy, v.29, i.1, pp. 87-110, 2010.

WONG, C-Y.; FUNG, H-N. Caught-In or Breaking-Free from the Middle Income Trap: The Case of Malaysia. Seoul Journal of Economics, v.32, i.1, pp.1-22, 2019.

WORLD BANK. Human Capital Index, 2020. Retrieved from: https://datacatalog.worldbank.org/dataset/human-capital-index.

YASAR, M. Can Turkey Escape from the Middle-Income Trap? What Has Been Done? What Can Be Done? Lessons from South Korea. Seoul Journal of Economics, v.32, i.1, pp. 63-82, 2019.

YE, L.; ROBERTSON, P. E. On the Existence of a Middle-Income Trap. Economic Record, v.92, i.297, pp. 173-189, 2016. Available at: http://10.0.4.87/1475-4932.12245.

YUSUF, S. 2017. Middle-income countries: trapped or merely slowing? Asian-Pacific Economic Literature, v.31, i.2, pp. 19-29, 2017. Available at: http://10.0.4.87/apel.12190.

\section{About the author}

GlendaKruss-gkruss@hsrc.ac.za

Human Sciences Research Council, Cape Town, South Africa.

ORCID: https://orcid.org/0000-0002-0946-785X. 
Kruss

\section{About the article}

Submission received on May 05, 2020. Approved for publication on October 10, 2020 